Мануїлова К.В., кандидат юридичних наук, доцент, доцент кафедри міжнародного та європейського права Національного університету "Одеська юридична академія»

\title{
МІЖНАРОДНО-ПРАВОВИЙ РЕЖИМ НЕРОЗПОВСЮДЖЕННЯ ЯДЕРНОЇ ЗБРОЇ В СУЧАСНОМУ МІЖНАРОДНОМУ ПРАВІ
}

\begin{abstract}
Анотація. У статті розглядається режим нерозповсюдження ядерної зброї, який спрямований на забезпечення стабільності і безпеки в світі. Підкреслюється, що ядерна енергія стала важливим предметом міжнародної взаємодії майже одразу після того, як зробилося можливим іï практичне (воєнне, пізніше цивільне) використання. Останніми десятиліттями така взаємодія помітно активізувалася. Її головною метою було і є не допустити застосування ядерної зброї, основним засобом для чого залишається режим нерозповсюдження, тобто сукупність міжнародно-правових і політичних норм, спрямованих зафіксувати кількість володільців ядерної зброї. Основний інструмент режиму - контроль над ядерними матеріалами - залишається найвужчим місцем на шляху до ядерної зброї.

Ключові слова: режим нерозповсюдження, ядерна зброя, зброя масового знищення, ДНЯЗ, МАГАТЕ.
\end{abstract}

Постановка проблеми. Одним 3 основних чинників забезпечення міжнародного миру та безпеки $є$ запобігання розповсюдженню зброї масового ураження, зокрема ядерної зброї та технологій ії створення. У цих цілях особливу роль відіграє питання забезпечення режиму нерозповсюдження ядерної зброї, який, будучи сформований на основі численних двосторонніх та багатосторонніх міжнародних договорів, включає низку правових механізмів, серед яких механізми запобігання та протидії незаконному обігу ядерних матеріалів $€$ найважливішими.

Натепер перед людством як ніколи гостро постає проблема забезпечення надійності міжнародних і національних режимів нерозповсюдження ядерних матеріалів та технологій. Попри велику кількість універсальних і регіональних структур, вплинути на поведінку порушників цих режимів вельми непросто, особливо якщо вони перебувають поза рамками відповідних домовленостей (Індія, Пакистан, Ізраїль) або офіційно повідомляють про вихід з них (наприклад, заява КНДР про вихід 3 Договору про нерозповсюдження ядерної зброї (ДНЯЗ) 1968 року) [1].

Аналіз останніх досліджень і публлікацій. Проблема розповсюдження ядерної зброї стала однією з головних тем у доктрині міжнародного права в 1960-1980рр. Цією проблемою займалися такі відомі вчені, як: О.В. Богданов, А.І. Вавилов, В.Ф. Давидов, В.Н. Денисов, Г.А. Смирнов, А.Н. Талалаєв, С.А. Тарасенко та низка інших учених, які зробили великий вклад у розробку проблеми. Спеціальне дослідження міжнародного режиму нерозповсюдження ядерної зброї присвятив Г.А. Смирнов, який захистив у 1979 році на цю тему кандидатську дисертацію. У 1987 році вийшла монографія Г.А. Осипова «Міжнародно-правовий режим нерозповсюдження ядерної зброї». Однак за останні десятиліття в галузі нерозповсюджен- ня ядерної зброї відбулися істотні зміни, що вимагають їх переосмислення і ретельного дослідження.

Загалом, характеризуючи ступінь наукової розробленості теми, можна констатувати, що нині у вітчизняній науці міжнародного права відсутні сучасні дослідження, присвячені міжнародно-правовому режиму нерозповсюдження ядерної зброї.

Формулювання мети статті. Першочерговим завданням світової спільноти є забезпечення універсальності і стабільності міжнародного режиму нерозповсюдження ядерної зброї. Саме це $\epsilon$ необхідністю більш глибокого вивчення міжнародно-правового режиму нерозповсюдження ядерної зброї, а також формулювання науково обгрунтованих пропозицій і рекомендацій, спрямованих на його підтримку і зміцнення.

Виклад основного матеріалу дослідження. Режим нерозповсюдження ядерної зброї спрямований на забезпечення стабільності і безпеки в світі. У 1963 році, коли тільки чотири держави мали ядерні арсенали, уряд Сполучених Штатів Америки робив прогноз, що протягом майбутнього десятиліття з'явиться від 15 до 25 держав, що володіють ядерною зброєю; інші ж держави передбачали, що це число може навіть зрости до 50. Побоювання з приводу появи ядерної зброї в політично нестабільній державі призвели до утворення закритого «Ядерного клубу» 3 п'яти перших країн-розробників ядерної зброї. Решта країн могли використовувати тільки «мирний атом» під міжнародним контролем. Ці ініціативи не викликали заперечень світової спільноти, більшість країн підписали Договір, добровільно відмовляючись від набуття ядерної зброї, більше того, в наступні роки були укладені договори, що забороняють використання ядерної зброї в низці регіонів світу. Ці регіони отримали статус без'ядерних зон.

Незаконний оборот ядерних матеріалів визначається як несанкціонована навмисна діяльність щодо перетинання або без перетинання міжнародних кордонів у вигляді отримання, постачання, володіння, використання, транспортування або утилізації радіоактивних матеріалів, включаючи ядерні, які можуть бути використані для виробництва ядерної зброї. Наявна система міжнародних договорів у галузі нерозповсюдження, а також нормативно-правові акти щодо безпечного використання ядерної енергії неспроможні протистояти викликам безпеки і контролю за ядерними матеріалами, що створює певні загрози ядерного тероризму в сценарії глобального росту атомної енергетики.

Розповсюдження атомних технологій, яке почалося в 1940-1950-х роках, швидко охопило багато країн. Це був етап «романтичного» захоплення атомом. Наукові дослідження, технологічні розробки та промислові застосування розгортались по широкому спектру, торкались як мирних, так і воєнних аспектів внутрішньоядерної енергії. У цей час практично і не проводилось принципіальне розмежування між ними. 
Нині на шляху розповсюдження ядерної зброї державами встановлено досить міцний заслін, який практично виключає iii незаконний оборот. Однак цього не можна сказати про ядерні матеріали, які можуть бути сировиною для створення такої зброї. Використання ядерних матеріалів як у мирних цілях, так і з метою створення зброї створює умови для розкрадання та подальшого незаконного обігу як самих матеріалів, так і їхніх відходів.

Протягом більш ніж піввікового досвіду використання ядерної енергії міжнародним співтовариством під егідою ООН, МАГАТЕ та іншими міжнародними організаціями ініціювався й здійснювався контроль за реалізацією основних національних і міжнародних програм з ядерної та радіаційної безпеки. Конвенції в галузі ядерної безпеки, ефективні національні системи регулювання, стандарти ядерної безпеки, а також механізми оцінювання в рамках МАГАТЕ $є$ важливими передумовами для створення світовим співтовариством глобального режиму ядерної й радіаційної безпеки. Безпечне використання ядерної енергетики нині зумовлено жорстким дотриманням міжнародних угод, які стосуються практично кожного аспекту ядерної та радіаційної безпеки. Погоджені на міжнародному рівні норми, рекомендації та керівні принципи нині охоплюють практично всі етапи ядерних операцій - від видобутку руди і виготовлення ядерного палива до видалення ядерних відходів [2, с. 11-12].

Глобальний режим ядерного нерозповсюдження уможливив досягнення значних успіхів у справі обмеження подальшого поширення ядерної зброї, хоча повністю запобігти поширенню цієї зброї й технології ії створення не вдалося [3, с. 12].

Міжнародне співробітництво в протидії незаконному обороту ядерних матеріалів включає співпрацю в обміні відповідною інформацією щодо обороту ядерних матеріалів і боротьби 3 ним; прийняття спільних зусиль з метою запобігання і припинення обороту ядерних матеріалів; запобігання і припинення використання своєї території для підготовки ядерної зброї; запобігання фінансуванню діяльності щодо обороту ядерних матеріалів; розширення співпраці в галузі боротьби з оборотом ядерних матеріалів шляхом укладення спеціальних міжнародних договорів і швидкого втілення їх у життя; приведення свого внутрішнього законодавства у відповідність до міжнародних договорів у сфері боротьби з обігом ядерних матеріалів; надання один одному всебічного сприяння в зв'язку з кримінальними розслідуваннями чи кримінальним переслідуванням у разі незаконного обороту ядерних матеріалів [4, с. 567].

Широкомасштабне використання атомної енергії передбачає встановлення співробітництва на багатосторонній та двосторонній основі. Таке співробітництво спрямоване насамперед на нерозповсюдження ядерної зброї і виключення використання мирних ядерних об'єктів, установок і матеріалів у військових цілях (нерозповсюдження); забезпечення безпечного використання атомної енергії; оперативне оповіщення та допомогу в разі ядерної аварії та інших інцидентів; відшкодування шкоди, заподіяної в результаті використання атомної енергії; проведення наукових досліджень; регулювання торгівлі й обміну ядерними матеріалами і технологіями, будівництва атомних електростанцій, реакторів і установок; зберігання і переробку відпрацьованого ядерного палива та радіоактивних відходів.

Міжнародно-правова база протидії незаконному обігу ядерних матеріалів представлена великим масивом норм, що являють собою як міжнародні договори, так і рішення міжнародних організацій. Разом з тим норми міжнародного права не закріплюють однакового понятійного апарату щодо незаконного обігу. Також норми міжнародного права не дають чіткої відповіді на питання щодо того, хто і якою мірою може виступати суб'єктом такого правопорушення. Крім того, існують проблеми правозастосування в частині кваліфікації національними правоохоронними органами конкретних дій як незаконного обігу ядерних матеріалів. Така кваліфікація не завжди однозначна.

Незважаючи на розвиток позитивних тенденцій у галузі забезпечення міжнародної ядерної безпеки, в останнє десятиліття XX ст. внаслідок соціально-політичних та економічних змін у суспільстві, системної кризи й розбіжностей між державами виникли реальні об'єктивні й суб' єктивні передумови, що негативно впливають на подальше використання ядерної енергії в мирних та військових цілях. Це призвело до появи нових викликів і загроз, які створюють реальну небезпеку міжнародному миру і стабільності.

Події останнього часу засвідчують, що окремі державні й недержавні суб'єкти не ослабляють зусиль щодо придбання ядерно-радіаційних матеріалів, технологій і товарів, пов'язаних з розробкою зброї масового знищення. Для досягнення цієї мети вони намагаються віднайти слабкі місця в міжнародних угодах і законодавствах країн у галузі експортного контролю, реалізувати на практиці різні обхідні схеми для закупівлі й постачання товарів і необхідних передових технологій. Наявний стан справ у сфері ядерних технологій і ядерних озброєнь надає широкий простір для інтерпретації тих чи інших подій як загрози й приводів для відмови від зобов'язань щодо дотримання міжнародних режимів.

До чинників, які викликають найбільше занепокоєння, належить таке негативне явище, як незаконний обіг ядерно-реактивних матеріалів. Одиничні інциденти розкрадання ядерно-реактивних матеріалів, зафіксовані на початку 1980-х років, нині характеризуються неухильним ростом випадків несанкціонованого поширення, перетворюються майже на масове явище.

Незаконний обіг ядерних матеріалів не тільки посилив наявні загрози в ядерній сфері, а й створив абсолютно нову загрозу «ядерного тероризму». По-перше, використання ядерних матеріалів зі злочинною метою сприяє радикальним державам у їхніх зусиллях обійти ретельно розроблені механізми контролю міжнародного режиму нерозповсюдження для створення ядерної зброї. Якщо у 1970-х роках для створення ядерного підривного пристрою були потрібні зусилля всієї держави, дорога широкомасштабна програма, то нині науково-технічний прогрес, поширення знань і технологій зробили цей процес доступнішим. По-друге, розкрадання, транспортування, несанкціонований обіг ядерних матеріалів може призвести до серйозного ядерно-радіаційного інциденту, опромінення населення, радіаційного забруднення навколишнього середовища. По-третє, можливість використання ядерних матеріалів iз терористичною метою створює реальну загрозу світовому співтовариству внаслідок неможливості забезпечення ефективного захисту від іонізуючого радіаційного випромінювання, його тривалої післядії, найбільшої уразливості для населення й навколишнього середовища в результаті радіаційного забруднення, а також найсильнішого психологічного впливу.

Такою зброєю може виступити ядерна бомба, а також різні форми радіологічної зброї. Ядерна зброя заснована на миттє- 
вій ланцюговій реакції поділу ядр важких атомів, кінетичній енергії, що вивільняється при цьому, і випромінюваній радіації. У термоядерному вибуховому пристрої використовується енергія синтезу ядр легких атомів. На відміну від нього, вражаючим чинником радіологічної зброї є постійний радіаційний фон, що розщеплюються, який руйнує ДНК живих клітин організмів $[5$, c. 310$]$.

Радіологічна зброя вважається зброєю масового ураження, а не знищення, на відміну від ядерної бомби. Негативні наслідки від теракту з використанням такої зброї включають не тільки радіаційне зараження, а й проблему дестабілізації суспільства, паніки, забруднення інформаційного поля. Низка дослідників вважає, що радіологічний тероризм можна розглядати і як форму інформаційного тероризму [6, с. 535].

Протягом останніх 60 років міжнародне співтовариство створило багатосторонній механізм попередження актів тероризму, а також нерозповсюдження зброї масового знищення. Науково-технічний прогрес, зростання терористичної активності зумовлюють появу як нових видів тероризму, так i нових міжнародних механізмів боротьби з ним (наприклад, Міжнародна конвенція про боротьбу з актами ядерного тероризму 2005 року). 3 огляду на той факт, що збиток від актів ЗМЗ-тероризму становить небезпеку для всього міжнародного співтовариства, ключове значення в міжнародному праві набуває завдання запобігання таких терористичних актів. Причому однією з особливостей превенції має стати і певний характер нових міжнародних норм: вони мають охоплювати не тільки наявні, а й майбутні види зброї масового знищення та матеріали масового знищення (нині міжнародно-правове регулювання передбачено тільки щодо біологічної, хімічної, ядерної і радіоактивної зброї) [7].

Провідну роль у зусиллях світової спільноти з нерозповсюдження ядерної зброї та ядерного роззброєння відіграє Організація Об'єднаних Націй. Виходячи зі статутної мети ООН - підтримання миру та безпеки у світі, Організація робить значний внесок у справу нерозповсюдження ядерної зброї. Саме у цій галузі діяльність ООН проявилась найбільш яскраво та плідно.

ГА ООН обговорювала всі важливі ініціативи у галузі ядерної енергії та нерозповсюдження ядерної зброї, починаючи від «Плану Баруха». Було прийнято низку резолюцій про заборону ядерної зброї. ООН відіграла визначну роль у розробці та підписанні багатьох угод та договорів у галузі роззброєння та нерозповсюдження, включно із ДНЯЗ. ООН тісно співпрацює з організаціями, що відіграють помітну роль у підтриманні наявного режиму нерозповсюдження. Так, МАГАТЕ щороку надсилає до ГА ООН звіт про свою діяльність і він обговорюється на пленарному засіданні $[8$, с. 4].

Вперше гостра потреба у вирішенні проблем, пов'язаних 3 ядерною енергією, виникла вже на I сесії Генеральної Асамблеї ООН 10 січня 1946 року. У тому ж році була створена перша постійна комісії в системі $\mathrm{OOH}$ - Комісії з атомної енергії. У 1947 році СРСР висунув план співпраці держав щодо вирішення проблем, пов'язаних з ядерною зброєю. У плані було запропоновано: заборонити використання ядерної зброї в світі, позаяк вона є зброєю масового знищення; заборонити державам, що мають ядерну зброю, передавати іiі іншим державам, а держави, що не мають ядерної зброї, мають відмовитися від іії виробництва.

У 1957 році в рамках ООН було створено головний міжурядовий форум, який займається питаннями науково-технічного співробітництва в галузі мирного використання ядерної технології, - Міжнародне агентство з атомної енергії (МАГАТЕ). За допомогою МАГАТЕ держави-учасниці не тільки впорядкували міжнародне співробітництво в галузі мирного використання ядерної енергії, а й стали стежити за тим, щоб створена в рамках МАГАТЕ система контролю не давала можливості неядерних держав використовувати ядерну енергію у військових цілях. Нині широкий спектр послуг, програм і видів діяльності Агентства грунтується на потребах його 168 держав-членів.

Агентство було створено як незалежна міжурядова організація в системі ООН, а з появою Договору про нерозповсюдження ядерної зброї (ДНЯЗ) його робота набула особливого значення, оскільки ДНЯЗ зробив обов'язковим для кожної держави-учасниці укласти з МАГАТЕ угоду про гарантії.

Договір про нерозповсюдження ядерної зброї - багатосторонній міжнародний акт, розроблений Комітетом з роззброєння ООН з метою поставити міцну перепону на шляху розширення кола країн, що володіють ядерною зброєю, забезпечити необхідний міжнародний контроль за виконанням державами взятих на себе за Договором зобов'язань з тим, щоб обмежити можливість виникнення збройного конфлікту із застосуванням такої зброї; створити широкі можливості для мирного використання атомної енергії.

Останніми роками ситуація в сфері нерозповсюдження ядерної зброї істотно ускладнилася та є досить актуальною, оскільки технічні можливості їі створення мають уже низка країн, включаючи і ті, які прагнуть придбати «ядерний» статус. Це, а також активізація зусиль міжнародних терористичних організацій з придбання зброї масового знищення, матеріалів i технологій для іiі виробництва, об'єктивно ставлять розповсюдження ядерної зброї в число основних загроз стратегічної стабільності і міжнародної безпеки в XXI столітті.

Висновки. Таким чином, на основі проведеного аналізу можна зробити висновок, що ядерна енергія стала важливим предметом міжнародної взаємодії майже одразу після того, як зробилося можливим іiі практичне (воєнне, пізніше цивільне) використання. Останніми десятиліттями така взаємодія помітно активізувалася. Ї̈̈ головною метою було і є не допустити застосування ядерної зброї, основним засобом для чого залишається режим нерозповсюдження, тобто сукупність міжнародно-правових і політичних норм, спрямованих зафіксувати кількість легальних володільців ядерної зброї. Основний інструмент режиму - контроль над ядерними матеріалами залишається найвужчим місцем на шляху до ядерної зброї.

\section{Jimepamypa:}

1. Ганич Д.В. Проблема нераспространения ядерного оружия в Южной Азии и политика России, 2007. 234 с.

2. Ядерное нераспространение: учебное пособие для студентов высших учебных заведений. В 2-х томах. Том I / Под ред. Орлова В.А., Сокова Н.Н. Москва: ПИР-Центр, 2002. 528 с.

3. Bunn G., Timerbayev R. M. The Nuclear Nonproliferation Regime and Security Assurances to the Nonnuclear States. PIR Center. Scientific Notes. Moscow, 1996. № 1.

4. Антипенко В.Ф. Боротьба 3 сучасним тероризмом: міжнародно-правові підходи: монографія. Київ: Вид-во «ЮНОНА-М», 2002. 723 c

5. Ядерное оружие после «холодной войны» / под ред. А.Г. Арбатова, В.М. Дворкина; Московский центр Карнеги. Москва: Российская политическая энциклопедия (РОССПЭН), 2006. 560 с. 
6. Фененко А.В. Современная международная безопасность. Ядерный фактор / отв. ред. В.А. Веселов. Москва: Аспект Пресс, $2013.573 \mathrm{c}$.

7. Синякин И.И. Международно-правовой режим нераспространения оружия массового уничтожения в свете борьбы с международным терроризмом: автореф. дис. ... канд. юрид. наук: спец. 12.00.10. «Международное право; европейское право». Москва, $2010.27 \mathrm{c}$.

8. Inventory of International Nonproliferation Organizations and Regimes / Compiled by Roland M. Timerbayev and Meggen M. Watt. Monterey, CA: Center for Nonproliferation Studies, Monterey Institute of International Studies, 1995. 572 c.

Мануилова К. В. Международно-правовой режим нераспространения ядерного оружия в современном международном праве

Аннотация. В статье рассматривается режим нераспространения ядерного оружия, который направлен на обеспечение стабильности и безопасности в мире. Подчеркивается, что ядерная энергия стала важным предметом международного взаимодействия почти сразу после того, как стало возможным ее практическое (военное, позже гражданское) использование. В последние десятилетия такое взаимодействие заметно активизировалось. Его главной целью было и есть не допустить применение ядерного оружия, основным средством для чего остается режим нераспространения, то есть совокупность международно-правовых и политических норм, нацеленных зафиксировать количество обладателей ядерного оружия. Основной инструмент режима - контроль над ядерными материалами - остается узким местом на пути к ядерному оружию.

Ключевые слова: режим нераспространения, ядерное оружие, оружие массового уничтожения, ДНЯО, МАГАТЭ.

Manuilova K. International legal regime for the nonproliferation of nuclear weapons in modern international law

Summary. The article discusses the non-proliferation regime of nuclear weapons, which is aimed at ensuring stability and security in the world. It is emphasized that nuclear energy became an important subject of international interaction almost immediately after its practical (military, later civilian) use became possible. In recent decades such interaction has intensified markedly. Its main goal was and is to prevent the use of nuclear weapons, the main means for which remains the non-proliferation regime that is the totality of international legal and political norms aimed at fixing the number of possessors of nuclear weapons. The main tool of the regime - control over nuclear materials - remains a bottleneck on the path to nuclear weapons.

Key words: non-proliferation regime, nuclear weapons, weapons of mass destruction, NPT, IAEA. 